\title{
Prevalence of metabolic syndrome in obese prepubertal and pubertal children
}

\section{Obez prepubertal ve pubertal çocuklarda metabolik sendrom prevalansı}

\author{
Ayça TÖREL ERGÜRa
}

Kırıkkale University, School of Medicine, Department of Pediatrics, Division of Endocrinology, Kırıkkale, TURKEY

\begin{abstract}
Aim: Obesity associated with metabolic syndrome is characterized by glucose intolerance, insulin resistance, type 2 diabetes mellitus, dyslipidemia and other hormonal disorders in childhood. Unfortunately, if the preventive measures are not taken in time they become obese in the adult age. The prevalence of metabolic syndrome in the pediatric age group is still not well known in our country. The purpose of our study is to evaluate the prevalence of metabolic syndrome and other metabolic characteristics in the obese prepubertal and pubertal children.

Material and methods: We studied 70 obese children and adolescents. Each child was subjected to detailed examination including anthropometric measures, blood testing (biochemistry, blood fasting glucose, renal and hepatic function tests, lipids, electrolytes, hormonal testing including free T3, free T4, TSH, thyroid autoantibodies, fasting insulin levels and oral glucose tolerance test). The criteria of metabolic syndrome were defined according to modified WHO criteria. Homeostasis model assessment of insulin resistance (HOMA-IR) parameters were used as index of insulin resistance.

Results: Metabolic syndrome was found in $18.8 \%$ of cases. Metabolic syndrome was found in a significantly higher rate in the pubertal prepubertal group ( $P>0.05$ ). The data related with glucose homeostasis; fasting hyperinsulinemia, impaired glucose tolerance were $33.3 \%$ and $5.5 \%$ in the prepubertal group, where it was $64.7 \%$ and $23.5 \%$ in the pubertal group, respectively. Hypertension was observed in four pubertal cases (11.7\%). Dyslipidemia were identified in $41.6 \%$ and $41.1 \%$ in prepubertal and pubertal groups, respectively, with no significant differences $(P<0.05)$.

Conclusion: Metabolic syndrome prevalence especially abnormal glucose homoeostasis among the obese pediatric age group was quite high. We suggested that, early diagnosis, regularly follow-up and if needed, treatment will prevent beta-cell destruction and development of type 2 diabetes mellitus in these cases.
\end{abstract}

Key words: Childhood obesity, obesity prevalence, metabolic syndrome, diabetes mellitus 


\section{ÖZET}

Amaç: Çocukluk çağında Metabolik Sendrom (MS), ilişkili obezite glukoz intoleransı, insülin direnci, tip 2 diabet, dislipidemi ve diğer hormonal bozukluklarla karakterizedir. Ne yazık ki Maalesef bu olgular koruyucu önlemler alınmadığı taktirde erişkin yaşamda obez hale gelecektirler. Pediatrik yaşta MS prevelansı ülkemizde halen iyi bilinmemektedir. Bu amaçla çalışmamızda prepubertal ve pubertal çocuklarda MS ve diğer metabolik özelliklere ait prevelansın değerlendirilmesi amaçlandı.

Gereç ve Yöntemler: 70 obez çocuk çalışmaya alındı. Antropometrik ölçümleri içeren detaylı muayenesi yapılan herbir çocuğa, kan biyokimyası; kan şekeri, renal ve hepatik fonksiyon testleri, lipidler, elektrolitler, hormonal değerlendirme için fT3, fT4, TSH tiroid otoantikorları, açıı insülin seviyeleri ve OGTT uygulandı. Metabolik sendrom kriterleri modifiye WHO kriterlerine göre tanımlandı. "Homeostasis model assessment of insulin resistance" (HOMA-IR) parametresi insülin rezistans indeksi olarak kullanıldı.

Bulgular: Tüm olgularda MS prevalansı \%18,8 olarak saptandı. MS prepubertal gruba göre pubertal grupta anlamlı derecede yüksekti $(P>0,05)$. Glukoz homeostazına ilişkin bulgular, prepubertal grupta açlık hiperinsülinemisi, bozulmuş glukoz toleransı olup sırasıyla $\% 33,3$ ve $\% 5,5$ idi. Aynı bulgular pubertal grupta sırasıyla $\% 64,7$ ve $\% 23,5$ idi. Hipertansiyon $4(\% 11,7)$ pubertal vakada gözlendi. Prepubertal ve pubertal grupta dislipidemi sırasıyla $\% 41,6$ ve $\% 41,1$ olarak saptandı. Bu yönü ile anlamlı farklılık yoktu $(P<0,05)$.

Sonuçlar: Obez pediatrik yaş grubunda özellikle anormal glukoz homeostazını içeren MS prevelansı belirgin yüksek saptandı. Sonuç olarak bu olgularda erken tanı, düzenli izlem ve gerekirse tedaviyle, beta hücre yıkımının ve tip 2 diabet gelişiminin önlenebileceği düşünülebilir.

Anahtar kelimeler: Çocukluk çağı obezitesi,obezite prevelansı, metabolik sendrom, diabetes mellitus

\section{Introduction}

Obesity in early childhood increases the risk of premature illnesses and early death, raising public health concerns. Recent studies showed that prevalence of nutritional deficiencies and infectious diseases decreased while morbidity due to other causes such as diabetes and cardiac diseases in the pediatric age-group increased [1]. The prevalence of the diseases associated with obesity may be affected by environmental factors, lifestyle changes and economical status. Although the prevalence of childhood obesity was previously reported to be between $9.1-12.8 \%$ in Turkey [2], it seems that its prevalence still steadily increasing.

Since there is insufficient data for the prevalence of metabolic syndrome in obese prepubertal and pubertal children in our country, in this study we aimed to search the clinical, metabolic and biochemical characteristics and prevalence of metabolic syndrome of 70 obese children and adolescents.

\section{Material and Methods}

The study group consisted of 70 children and adolescents (the mean age $10.7 \pm 2.9$ years old) with obesity. All the cases were admitted to Kırıkkale University, Department of Pediatric Endocrinology and Diabetes. All the cases underwent a detailed physical examination, pubertal staging and anthropometric evaluation such as chronological age, height, weight, standing height. Height was expressed as SD score, body mass index as BMl: weight ( $\mathrm{kg}) /$ height (meters)
[2]. Children with BMI exceeding 95th percentile for age and sex is termed as obese [3]. The pubertal development stage was assessed by the same pediatric endocrinologist using the criteria of Tanner Stages [4]. In the physical examination, acanthosis nigricans reflexing insulin resistance was evaluated in each case (Figure 1).

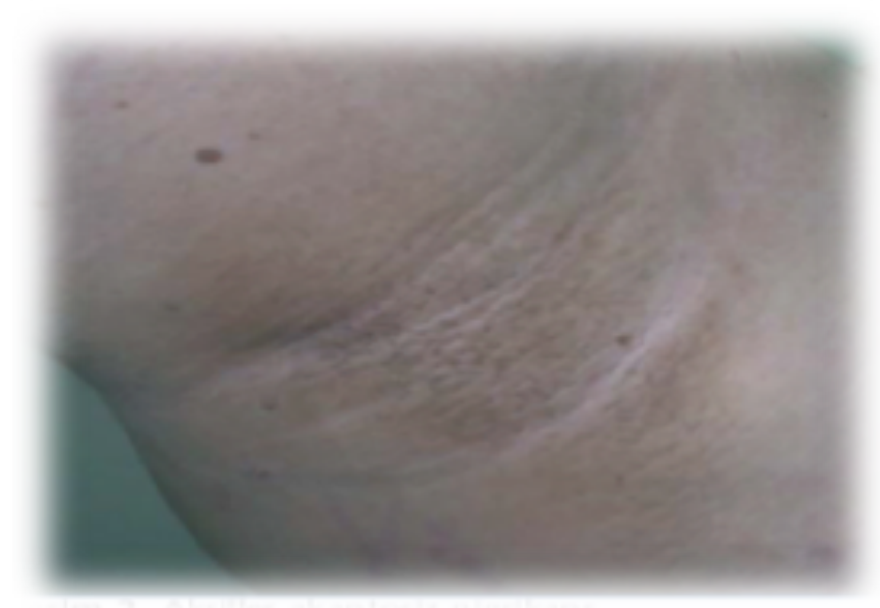

Figure 1. Appearance of axillary acanthosis nigricans

The height was measured to the nearest $0.5 \mathrm{~cm}$ on a standard height board, and the weight was determined to the nearest 0.1 $\mathrm{kg}$ on a standard physician's beam scale with the subject dressed only in light underwear and without shoes. Blood pressure was measured with a standard mercury sphygmomanometer after the cases had rested for at least $15 \mathrm{~min}$. 
Written informed consent was obtained from the parents. The inclusion and exclusion criteria of the study are shown in Table 1.

Table1. The inclusion and exclusion criteria

\begin{tabular}{|l|l|}
\hline The inclusion criteria & The exclusion criteria \\
\hline $\begin{array}{l}\text { 1. Cases between 4-17 years of age } \\
\text { without any chronical disease and } \\
\text { infection of any kind such as cardiac, } \\
\text { renal, hepatic, diabetes, cancer, } \\
\text { psychiatric diseases. }\end{array}$ & $\begin{array}{l}\text { 1. Cases with a prior major } \\
\text { illness; cardiac, renal, } \\
\text { hepatic, cancer, psychiatric } \\
\text { diseases and, type1 or } 2 \\
\text { diabetes. }\end{array}$ \\
\hline $\begin{array}{l}\text { 2. BMl>95th percentile for age and } \\
\text { gender based on the standards of } \\
\text { the Centers for Disease Control and } \\
\text { Prevention (CDC) }\end{array}$ & $\begin{array}{l}\text { 2. Cases taking medica- } \\
\text { tions such as glucocorti- } \\
\text { coids. }\end{array}$ \\
\hline
\end{tabular}

Blood fasting glucose, renal and hepatic function tests, lipids (total cholesterol, triglycerides, low-density lipoproteincholesterol (LDL), triglycerides, high-density lipoproteincholesterol (HDL), electrolytes, hormonal testing such as fT3, fT4, TSH, thyroid autoantibodies, fasting insulin levels. and an oral glucose tolerance test were performed in all cases. An oral glucose tolerance test (OGTT) was performed using a dose of $1.75 \mathrm{~g}$ glucose $/ \mathrm{kg}$ body weight (maximum of 75 g). Venous blood samples were obtained at 0, 30, 60, 120, 180 minutes to measure plasma glucose and plasma insulin levels in the morning by venipuncture after a night fasting [5]. Plasma glucose level was determined by the glucose oxidase method, plasma insulin was measured by using IMMULITE immunoassay. The criteria for obesity and metabolic syndrome, defined by WHO was shown in Table 2 [3].

Table 2. Criteria of metabolic syndrome which was defined as having $\geq 3$ of the following components

\begin{tabular}{|c|c|}
\hline 1. Obesity & BMI > 95th percentile for age and sex \\
\hline $\begin{array}{l}\text { 2. Abnormal glucose homeostasis } \\
\text { İmpaired fasting glucose } \\
\text { Fasting hyperinsulinemia } \\
\text { İmpaired glucose tolerance }\end{array}$ & $\begin{array}{l}\geq 100 \mathrm{mg} / \mathrm{dl} \\
\text { prepubertal }>15 \mathrm{mU} / \mathrm{L} ; \text { pubertal }>30 \mathrm{mU} / \mathrm{L} \\
\text { OGTT } 120 \mathrm{~min} ; 200 \mathrm{mg} / \mathrm{dl}>\text { plasma glucose level } \geq 140 \mathrm{mg} / \mathrm{dl}\end{array}$ \\
\hline 3. Hypertension & systolic blood pressure $>$ 95th percentile for age and sex \\
\hline 4. Dyslipidemia & $\begin{array}{l}<10 \text { years; > } 102 \mathrm{mg} / \mathrm{dl} \text { and }>10 \text { years; }>136 \mathrm{mg} / \mathrm{dl} \\
<35 \mathrm{mg} / \mathrm{dl}\end{array}$ \\
\hline $\begin{array}{r}\text { Low LDL-c } \\
\text { High Total -c }\end{array}$ & $>95$ th percentile \\
\hline
\end{tabular}

Homeostasis model assessment of insulin resistance (HOMAIR) parameter (fasting insulin $\times$ fasting glucose / $18 / 22.5$ ) ; was used as index of insulin resistance [6]. A cut-off HOMA-IR level of $>2.5$ in children and; $>4$ in adolescents was used to identify an insulin-resistance status [6].

Statistical analysis: For the statistical analysis SPSS (Inc Version 11.0 software) statistical programs was used. The results are expressed as mean and median values in qualitative variables and as a percentage. Abnormal glucose homeostasis (insulin resistance) parameters and metabolic syndrome prevalence's in the prepubertal and pubertal groups were estimated by chi-square test. The differences were tested by Student's test. Statistical significance was taken as $\mathrm{P}<0.05$.

\section{Results}

The study group consisted of 70 cases (ages between 4.6 to 16.3years) with obesity. The general characteristics, anthropometric values, glucose and lipid metabolism features of all the cases are shown in Table 3.
Table 3. Clinical characteristics of the cases

\begin{tabular}{|l|l|}
\hline Case $(\mathrm{n})$ & 70 \\
\hline Female & 36 \\
\hline Male & 34 \\
\hline Age (year) & $10.7 \pm 2.9$ \\
\hline BMI $(\mathrm{w} / \mathrm{h} 2 ; \mathrm{kg} / \mathrm{m} 2)$ & $26.7 \pm 4.5$ \\
\hline Systolic BP $(\mathrm{mmHg})$ & $109.8 \pm 14.1$ \\
\hline Diastolic BP $(\mathrm{mmHg})$ & $69.9 \pm 9.9$ \\
\hline Fasting glucose $(\mathrm{mg} / \mathrm{dl})$ & $88.3 \pm 9.2$ \\
\hline Fasting insulin $(\mathrm{IU} / \mathrm{L})$ & $20.7 \pm 15.4$ \\
\hline Glucose / insulin & $9.07 \pm 6.3$ \\
\hline IRHOMA & $3.48 \pm 3$ \\
\hline OGTT 120'glucose $(\mathrm{mg} / \mathrm{dl})$ & $114 \pm 25.8$ \\
\hline OGTT 120'insulin $(\mathrm{mg} / \mathrm{dl})$ & $88.9 \pm 17.4$ \\
\hline Total-cholesterol $(\mathrm{mg} / \mathrm{dl})$ & $179.9 \pm 32.4$ \\
\hline Triglycerides $(\mathrm{mg} / \mathrm{dl})$ & $126.7 \pm 76.1$ \\
\hline HDL-cholesterol $(\mathrm{mg} / \mathrm{dl})$ & $48.4 \pm 8.8$ \\
\hline LDL-cholesterol $(\mathrm{mg} / \mathrm{dl})$ & $106.9 \pm 29.9$ \\
\hline
\end{tabular}


Of the 70 obese children, $56(80 \%)$ had a positive family history for obesity. Achantosis nigricans was determined in $20 \%$ of the cases. Achantosis nigricans and hypertension were significantly more common in pubertal cases $(P<0.05)$. OGTT performed in 70 cases and the total abnormal glucose homoeostasis was identified in $67.1 \%$, hyperinsulinemia in $48.5 \%$, impaired glucose tolerance in $14.3 \%$ and none of the cases were determined as having impaired fasting glucose. Hyperinsulinemia, impaired glucose tolerance, high triglycerides were also more frequent in pubertal than prepubertal children. There was no significant differences in the prevalence of metabolic syndrome by gender.

Table 4 shows the prevalence of metabolic syndrome of prepubertal and pubertal cases. In this according with metabolic syndrome was found in $20(58.8 \%)$ cases in pubertal cases, $12(33.3 \%)$ cases in prepubertal cases. Metabolic syndrome was significantly more frequent among pubertal cases than prepubertal cases.

Table 4. Anthropometric values and metabolic syndrome parameters in prepubertal and pubertal cases

\begin{tabular}{|l|l|l|l|l|}
\hline \multicolumn{1}{|c|}{ Parameter } & \multicolumn{1}{|c|}{ Prepubertal } & \multicolumn{1}{c|}{ Pubertal } & \multicolumn{1}{c|}{ P } & \multicolumn{1}{c|}{ Total } \\
\hline $\mathrm{n}(\%)$ & $36(51.4 \%)$ & $34(48.5 \%)$ & NS* & 70 \\
\hline Female/Male & $19 / 17$ & $18 / 16$ & NS* & \\
\hline Age (year) & $7.97 \pm 1.9$ & $13.2 \pm 1.89$ & $<0.05$ & \\
\hline BMI (kg/m2) & $26.7 \pm 3.5$ & $31.1 \pm 4.8$ & $<0.05$ & $47(67.1 \%)$ \\
\hline Abnormal glucose homeostasis & $19(52.7 \%)$ & $28(82.4 \%)$ & $<0.05$ & $34(48.5 \%)$ \\
\hline Hyperinsulinemia & $12(33.3 \%)$ & $22(64.7 \%)$ & $<0.05$ & $10(14.3 \%)$ \\
\hline Impaired glucose tolerance & $2(5.5 \%)$ & $8(23.5 \%)$ & $<0.05$ & - \\
\hline Impaired fasting glucose & - & - & - & $21(30 \%)$ \\
\hline Elevation of IR-HOMA & $7(19.4 \%)$ & $14(41.2 \%)$ & $<0.05$ & $29(41.4 \%)$ \\
\hline Dyslipidemia & $15(41.6 \%)$ & $14(41.1 \%)$ & NS* & $36(51.4 \%)$ \\
\hline High total cholesterol & $17(42.7 \%)$ & $19(55.8 \%)$ & NS* & $35(50 \%)$ \\
\hline High triglycerides & $10(27.7 \%)$ & $25(73.5 \%)$ & $<0.05$ & $18(25.7 \%)$ \\
\hline Low HDL cholesterol & $8(22.2 \%)$ & $10(29.4 \%)$ & NS* & $4(5.7 \%)$ \\
\hline Hypertension & - & $4(11.7 \%)$ & $<0.05$ & $18(25.7 \%)$ \\
\hline Acanthosis nigricans & $6(22.2 \%)$ & $12(35.3 \%)$ & $<0.05$ & $32(45.7 \%)$ \\
\hline Metabolic syndrome & $12(33.3 \%)$ & $20(58.8 \%)$ & $<0.05$ & \\
\hline
\end{tabular}

Abbrev: NS: nonsignificant

Ten cases were diagnosed as subclinical hypothyroidism. The mean serum TSH level was $6.1 \pm 1.24 \mathrm{IU} / \mathrm{L}$. Thyroid autoantibody positivity was not observed in any of the cases.

\section{Discussion}

Recent studies have shown an increase in the prevalence of metabolic syndrome in obese children and adolescents [1]. The metabolic syndrome is defined by a combination of obesity, hypertension, dyslipidemia, abnormal glucose metabolism such as hyperinsulinism, insulin resistance, impaired fasting glucose tolerance, impaired glucose tolerance and/or type 2 diabetes mellitus [1]. Besides obesity, low birth weight, increased gain in body mass in early childhood, decreased pubertal insulin sensitivity and clinical markers of insulin resistance (acanthosis nigricans, polycystic ovarian syndrome, premature adrenarche) increased risk of metabolic syndrome [7].
The prevalence of obesity and associated metabolic syndrome in children and adolescents still seems to steadily increasing in Turkey. So obesity in children and adolescents has become a major public health issue in our country. Obese children have a high risk to become obese adults with a high risk for the occurrence of type 2 diabetes, cardiovascular, orthopaedic, bone and other diseases. The most effective tool for prevention of metabolic syndrome is to avoid the development of childhood obesity. Unfortunately, besides several studies, there is not enough knowledge about the prevalence of glucose and/or lipid abnormalities and metabolic syndrome in obese children in Turkey.

In our study the prevalence of abnormal glucose metabolism in obese cases was found as $67.1 \%$. None of the cases had impaired fasting glucose or type 2 diabetes, while 10 obese 
cases had impaired glucose tolerance. In a study from Southern Italy, the prevalence of insulin resistance was found as $40.8 \%$ in obese children and as $41.2 \%$ in obese adolescents. None of the subjects had impaired fasting glucose or diabetes as in our study, while 4 obese patients had impaired glucose tolerance (4\%). According to this study; impaired glucose tolerance is still rare whereas insulin-resistance is already detectable in more than $40 \%$ of obese children and adolescents in Southern Italy [8].Their observations confirm that metabolic risk factors can be found at a very early age and strengthen the case for implementing programs for prevention and treatment of childhood obesity. In a study from Spain, the prevalence of insulin resistance in obese children was found 35.8\%, impaired glucose tolerance was found in $7.4 \%$, but there was no case with type 2 diabetes mellitus [8]. Our findings as high prevalence of insulin resistance in obese children, were in conformity with both studies.

In another study; Wiegand et al reported that the prevalence of abnormal glucose tolerance and type 2 diabetes were $7.5 \%$ and $1.2 \%$, respectively in 491 obese European children and adolescents [9]. Accordingly, the incidence of childhood obesity and type 2 diabetes is an increasing problem in Europe. Impaired glucose tolerance and type 2 diabetes are far more common in obese European children of Caucasian origin than previously thought. Therefore, using fasting glucose levels as the main screening tool appears to be insufficient in detecting these children. Wiegand et al reported that the percentage of type 2 diabetes in the obese pediatric cases was very high [9]. In our study we did not determine type 2 diabetes in the obese cases. An increased prevalence of type 2 diabetes mellitus in obese children and adolescents, especially in specific ethnic subgroups was observed. The prevalence of type 2 diabetes mellitus in a large group of 520 Caucasian children and adolescents with obesity living in Germany was assessed. They reported that $1.5 \%$ $(n=8)$ of the obese cases were type 2 diabetes while impaired fasting glucose was detected in $3.7 \%(n=19)$ and impaired glucose tolerance in $2.1 \%(n=11)$ of the patients [9]. Screening for diabetes in severely obese children and adolescents (BMISDS > 2.5) was therefore recommended [9].

In an extensive work, "Bogalusa Study" made by Chen et al on children at pediatric age group the metabolic syndrome was found to be $4 \%$ in white and $3 \%$ in black children [10]. In another extensive research made on Finnish children and adolescents investigating cardiovascular risk factors, the incidence of metabolic syndrome was determined as 4\% [11]. In USA, in the third National Health and Nutrition Research during 1988-1994 the metabolic syndrome frequency was found to be $4.2 \%(6.1 \% \mathrm{n}$ males and $2.1 \%$ in females) [12]. In the same investigation in obese adolescents (BMI > 95 percentiles) the frequency of metabolic syndrome was found to be $28.7 \%$ and in overweight cases (between BMI 85-95 percentiles) $6.8 \%$. In a study made recently on obese adolescents of metabolic syndrome was found to be $30 \%$ and it was noted that with the decrease of insulin sensitivity, the metabolic syndrome components increased [13]. Babaoğlu et al. determined impaired fasting and glucose metabolism in $14.2 \%$ of 105 children aged $10-18$ years in a multicentre study [14]. Atabek et al. found metabolic syndrome to be $27.2 \%$ in 169 obese children and adolescents [2].

In this study we determined MS in prepubertal cases considerably frequent. Some studies showed that, exposure to environmental factors in utero (maternal diabetes or obesity) increases the risk of developing childhood MS and also the risk of early stages of cardiovascular disease [15]. Longitudinal studies of Pima Indian children demonstrated that birth weight, i.e., either small for gestational age (SGA) or large for gestational age (LGA), exposure to diabetes in utero, and obesity are the major factors in the development of childhood MS [16].

As a conclusion, we think that Turkish clinicians should screen obese children and adolescents from the point of view of metabolic syndrome. Multicentre, population based diabetes screening programs in accordance with the model protocol suggested by WHO are essential for the estimation and determination of metabolic syndrome prevalence in Turkey.

\section{Declaration of conflicting interests}

The authors declared no conflicts of interest with respect to the authorship and/or publication of this article.

\section{Funding}

The authors received no financial support for the research and/or authorship of this article.

\section{References}

1. Knerr I. Obesity and metabolic syndrome in children and adolescents. MMW Fortschr Med 2004; 146: 41-3.

2. Atabek EA, Pirgon $O$, Kurtoğlu S. Prevalence of metabolic syndrome in obese Turkish children and adolescents. Diab Res Clin Pract 2006; 72: 315-21.

3. Alberti KG, Zimmet PZ. Definition, diagnosis and classification of diabetes mellitus and its complications. Part 1: diagnosis and classification of diabetes mellitus provisional report of a WHO consultation. Diab Med 1998; 15: 539-53. 
4. Marshall WA, Tanner JM. Variations in pattern of pubertal changes in girls. Arch Dis Child 1969; 44: 291-303.

5. ISPAD Clinical practice consensus guidelines 2014 Compendium. Definition, epidemiology and classification of diabetes in children and adolescents. In: Craig ME, Jefferies C, Dabelea D et al. Pediatric Diabetes 2014: 15 (Suppl.20) 4-17.

6. Conwell LS, Trost SG, Brown WJ, Batch JA. Indexes of insulin resistance and secretion in obese children and adolescents. Diab Care 27: 2004; 314-9.

7. Barkai L, Paragh G. Metabolic syndrome in childhood and adolescence. Orv Hetil 2006; 147: 243-50.

8. Valerio $G$, Licenziati $M R$, lannuzi $A$ et al. Insulin resistance and impaired glucose tolerance in obese children and adolescents from Southern Italy. Nutr Metab Cardiovasc Disease 2006; 16: 279-84.

9. Wiegand S, Maikowski U, Blankenstein $O$ et al. Type 2 diabetes and impaired glucose tolerance in European children and adolescents with obesity - a problem that is no longer restricted to minority groups. Eur J Endocrinol 2004; 151: 191-206.

10. Chen W, Bao W, Begum S, Elkasabany A, Srinivasan SR, Berenson GS. Age-related patterns of the clustering of cardiovascular risk variables of syndrome $X$ from childhood to young adulthood in a population made up of black and white subjects: the Bogalusa Heart Study. Diabetes 2000; 49: 1042-48.
11. Raitakari OT, Porkka KV, Ronnemaa $\mathrm{T}$, et al. The role of insulin in clustering of serum lipids and blood pressure in children and adolescents. The cardiovascular risk in young Finns study. Diabetologia 1995; 38: 1042-50.

12. Cook $S$, Weitzman $M$, Auinger $P$, Nguyen $M$, Dietz WH. Prevalence of a metabolic syndrome phenotype in adolescents: findings from the third National Health and Nutrition Examination Survey, 1988-1994. Arch Pediatr Adolesc Med 2003; 157: 821-7.

13. Cruz ML, Weigensberg MJ, Huang TT, Ball G, Shaibi GQ, Goran MI. The metabolic syndrome in overweight Hispanic youth and the role of insulin sensitivity. J Clin Endocrinol Metab 2004; 89: 108-13.

14. Babaoğlu K, Hatun S, Arslanoğlu I, et al. Evaluation of glucose intolerance in adolescents relative to adults with type 2 diabetes mellitus. J Pediatr Endocrinol Metab 2006; 19: 1319-26.

15. Boney CM, Verma A, Tucker R, Vohr B. Metabolic syndrome in childhood: association with birth weight, maternal obesity, and gestational diabetes mellitus. Pediatrics 2005; 115: 290-6.

16. Dabelea $D$, Hanson $R$, Lindsay $R$, et al. Intrauterine exposure to diabetes conveys risk for type 2 diabetes and obesity: a study of discordant sibships. Diabetes 2000; 49: 2208-11. 